Dig Dis 1996;14:330

\title{
Genetic Hemochromatosis
}

\begin{tabular}{|l|l|l|}
\hline G.S. & Gary S. & Tennyson $^{\mathrm{a}}$ \\
\hline S.R. & Sami R. & Achem $^{\mathrm{b}}$ \\
\hline
\end{tabular}

${ }^{\mathrm{a} D e p a r t m e n t}$ of Pathology, and ${ }^{\mathrm{b}}$ Division of Gastroenterology, University of Florida, Jacksonville, Fla., USA

Sami R. Achem, MD, FACP, University of Florida/Jacksonville, Division of Gastroenterology, 653 West 8th Street, Room 3045, Jacksonville, FL 32209-6511 (USA)

A A low-power view shows panlobular deposition (graded 4+) of a finely granular brown pigment, most prominent in hepatocytes ('hepatocellular iron'). There are small, focal collections of iron in Kupffer cells and portal tracts. HE. $\times 40$.

B A high-power microscopic view confirms the hepatocellular deposition of the granular pigment, with lesser amounts in sinusoidal Kupffer cells. HE. $\times 400$.

C A high-power view of a section stained with Prussian Blue confirms that the pigment is iron. Prussian Blue. $\times 400$. 